\title{
MENINGKATKAN KINERJA GURU MELALUI SUPERVISI AKADEMIK KEPALA SEKOLAH DENGAN PENDEKATAN INDIVIDUAL DI SMPN 7 NANGAPANDA
}

\author{
Natalia Nata ${ }^{1}$, Melkyanus Kaleka ${ }^{2}$ \\ ${ }^{1}$ SMP Negeri 7 Nangapanda \\ ${ }^{2}$ Fakultas Keguruan dan Ilmu Pendidikan Universitas Flores \\ e-mail: nata32882@gmail.com
}

\begin{abstract}
ABSTRAK
Penelitian ini bertujuan untuk meningkatkan kinerja guru-guru di Sekolah Menengah Pertama Negeri 7 Nangapanda khususnya pada bidang adminitrasi pembelajaran dan pelaksanaan pembelajaran. Penelitian ini merupakan Penelitian Tindakan Sekolah yang dilaksanakan dalam 2 siklus. Setiap siklus mencakup 4 tahapan yaitu; perencanaan, pelaksanaan, observasi, dan refleksi. Subjek dalam penelitian ini terdiri dari 10 orang guru. Teknik pengumpulan data yaitu menggunakan teknik observasi, kuesioner dan wawancara. Kesimpulan dari hasil penelitian ini adalah; (1) terdapat peningkatan kinerja guru bidang administrasi pembelajaran yaitu ditunjukkan dari hasil yang diperoleh pada siklus I dimana dari 4 orang guru yang tuntas $(40 \%)$, dan pada siklus II meningkat menjadi 10 orang telah tuntas (100\%). (2) ada peningkatan kinerja guru bidang pelaksanaan pembelajaran yaitu ditunjukkan dari hasil yang diperoleh pada siklus I dimana 7 orang guru yang tuntas $(70 \%)$, dan pada siklus II meningkat menjadi 10 orang telah tuntas $(100 \%)$.
\end{abstract}

Kata Kunci: kinerja guru, supervisi kepala sekolah, pendekatan individual

\section{ABSTRACT}

This study aims to improve the performance of teachers in Nangapanda 7 Public Middle School, especially in the area of learning administration and learning implementation. This research is a School Action Research conducted in 2 cycles. Each cycle includes 4 stages namely; planning, implementation, observation, and reflection. The subjects in this study consisted of 10 teachers. Data collection techniques are using observation, questionnaires and interviews. The conclusions from the results of this study are; (1) there is an increase in the performance of teachers in the field of learning administration that is shown from the results obtained in the first cycle where of 4 teachers who completed (40\%), and in the second cycle increased to 10 people have completed (100\%). (2) there was an increase in the performance of teachers in the implementation of learning that is shown from the results obtained in the first cycle where 7 teachers were complete (70\%), and in the second cycle increased to 10 people had been completed (100\%).

Keywords: teacher performance, supervision of school principals, individual approaches 


\section{PENDAHULUAN}

Peran guru yang strategis, menuntut kerja guru yang profesional, dan mampu mengembangkan ragam potensi yang terpendam dalam diri peserta didik. Sedemikian besar peran guru dalam melakukan perubahan terhadap peradaban lewat anak didik yang akan menuntut kemajuan masa depan. Tetapi disisi lain guru dihadapkan pada sejumlah permasalahan antara lain memantapkan kompetensi guru sesuai UU No.14 tahun 2005 yaitu kompetensi pedagogik, kompetensi profesional, kompetensi kepribadian, dan kompetensi sosial. Tentu ada diantara guru sulit untuk memahaminya apalagi mengimplementasikan. Permasalahan ini tentu saja guru membutuhkan bantuan untuk mengatasi kesulitannya. Orang yang paling dekat dan dipandang mampu untuk membantu mengatasi kesulitan guru tersebut adalah kepala sekolah dan pengawas sekolah melalui kegiatan supervisi.

Kinerja guru merupakan tingkat keberhasilan guru dalam menyelesaikan pekerjaannya. Kinerja guru tidak hanya ditunjukkan oleh hasil kerja akan tetapi juga ditunjukkan oleh perilaku dalam bekerja, mulai dari perencanaan pembelajaran, dalam pelaksanaan pembelajaran dikelas dan proses evaluasi atau penilaian hasil belajar siswa. Menurut Supardi (2013: 54), kinerja guru dapat diartikan sebagai kemampuan sorang guru dalam melaksanakan tugas pembelajaran di sekolah dan bertanggung jawab atas peserta didik di bawah bimbingannya dengan meningkatkan prestasi belajar peserta didik. Suharsaputra (2010: 176) menjelaskan bahwa kinerja guru adalah perilaku yang dihasilkan seseorang dalam melaksanakan tugasnya sebagai pendidik dan pengajar ketika mengajar di depan kelas. Standar kinerja ini terdapat di dalam Undang-Undang Republik Indonesia Nomor 14 Tahun 2005 pasal 8 tentang Guru dan Dosen bahwa guru wajib memiliki kualifikasi akademik, kompetensi, sertifikat pendidik, sehat jasmani dan rohani, serta memiliki kompetensi untuk mewujudkan tujuan pendidikan nasional.

Berdasarkan pendapat di atas dapat penulis definisikan bahwa kinerja guru adalah penampilan kerja seorang guru dalam pembelajaran sebagai realisasi dari kompetensi yang dimilikinya guna memperoleh hasil belajar peserta didik yang masiksimal. Dan pada prinsipnya kinerja mengarah pada suatu upaya dalam rangka mencapai prestasi kerja yang lebih baik. Terdapat 3 pokok dari kinerja guru yaitu; bidang kurikulum, pembelajaran dan pengelolaan atau manajemen kelas. Sesuai dengan bidang kerja kepala sekolah, seorang kepala sekolah bertanggung-jawab terhadap kualitas proses dan hasil pembelajaran yang dilakukan oleh guru di sekolah yang dipimpinnya. Kualitas pembelajaran guru niscaya akan dapat ditingkatkan, ketika guru tersebut berkompeten dalam menjabarkan kurikulum (dalam hal ini adalah KTSP 2013) ke dalam perangkat-perangkat kurikulum: silabus, RPP, KKM, rencana evaluasi, melaksanakan implementasi pembelajaran, dan melaksanakan pengelolaan kelas. Uno dan Lamatenggo (2012: 70) menyebutkan bahwa terdapat beberapa indikato kinerja guru yaitu; (a) menguasai bahan; (b) mengelola proses belajar mengajar; (c) mengelola kelas; (d) menggunkan media atau sumber belajar; (e) menguasai penyediaan kondisi dan situasi kegiatan akademik yang menguntungkan guru yang akan mengajar dan murid yang akan belajar. Manurut Sa'ud (2011: 50), dalam proses pembelajaran seorang guru harus memiliki kemampuan dalam hal; (1) merencanakan proses pembelajaran, (2) melaksanakan dan mengelola proses pembelajaran, (3) menilai kemajuan proses pembelajaran, dan (4) menguasai bahan pelajaran. Selain itu diungkapkan juga oleh Mulyasa (2013: 103) bahwa kinerja guru dalam pembelajaran berkaitan dengan kemampuan guru dan merencanakan, melaksanakan, dan menilai pembelajaran, baik yang berkaitan dengan proses maupun hasilnya.

Permasalahan dalam Penelitian Tindakan Sekolah ini adalah belum semua guru di SMPN 7 Nangapan menyiapkan administrasi pembelajaran dengan baik, serta kegiatan pelaksanaan pembelajaran yang belum maksimal. Untuk itu kinerja guru perlu dilakukan 
perbaikan melalui kegiatan supervisi kepala sekolah. Supervisi dapat dilakukan dalam bentuk pembinaan dan bantuan yang diberikan kepala guru untuk mengembangkan situasi belajar mengajar agar menjadi lebih baik. Supervisi akademik adalah serangkaian kegiatan membantu guru mengembangkan kemampuannya mengelola kegiatan pembelajaran guna mencapai tujuan (Glikman, et al; 2007). Supervisi akademik dapat melihat kondisi nyata kinerja guru untuk menjawab pertanyaan-pertanyan, misalnya apa yang terjadi dikelas?, aktivitas apa yang bermakna bagi guru? apa yang telah dilakukan guru untuk menyiapkan proses pembelajaran?. Berdasarkan jawaban dari pertanyan-pertanyan tersebut akan diperoleh informasi mengenai kemampuan atau kinerja guru (Osnal, 2016). Selanjutnya Sutisna menjelaskan bahwa supervisi merupakan upaya sekolah dalam menciptakan semangat mengajar yang bermutu (Suhardan, 2010: 200).

Dari penjelasan beberapa para ahli di atas, dapat disimpulkan bahwa supervisi kepala sekolah merupakan suatu bentuk layanan, bimbingan, bantuan dan pengawasan yang dilakukan oleh kepada sekolah untuk mengembangakan, memperbaiki, dan peningkatan kualitas mengajar guru. Dalam penelitian ini kinerja guru lebih difokuskan pada kinerja guru bidang administrasi atau perangkat pembelajaran dan kinerja guru dalam pelaksanaan pembelajaran. Melalui penelitian tindakan sekolah (PTS) dapat memperbaiki situasi akademik guru dan manajerial kepala sekolah (Wayan, AS., 2010).

Kegiatan Supervisi di SMP Negeri 7 Nangapanda sudah dijalankan sejak Tahun Pelajaran 2017/2018. Supervisi dilakukan oleh kepala sekolah dan dibantu oleh guru senior yang ditunjuk oleh kepala sekolah. Supervisi yang dilakukan di SMP Negeri 7 Nangapanda adalah supervise akademik, dimana yang disupervisi adalah kesiapan administrasi guru dan kegiatan belajar mengajar di kelas. Instrumen yang digunakan kurikulum 2006. Untuk administrasi sejauh ini terkadang guru mengerjakan administrasi masih asal-asalan saja atau hanya dengan copy paste untuk memenuhi tuntutan sekolah. Sedangkan pada kegiatan belajar mengajar guru masih belum mempersiapkan komponen rencana dan pelaksanaan pembelajaran dengan baik. Misalkan dalam pemilihan sumber belajar dan metode pembelajaran. Melalui pelaksanaan supervisi akademik kepala sekolah diharapkan dapat meningkatkan kinerja dan motivasi guru dalam mempersiapkan dan melaksanakan kegiatan pembelajaran, (Erni, 2017; Wiwin, Endang, Cicih, 2016; Karsiyem, Wangid, 2015).

Sejalan dengan perubahan kurikulum yakni dari KTSP 2006 ke KTSP 2013 ada banyak administrasi yang harus dikerjakan oleh seorang guru. Kurikulum 2013 mengamatkan bahwa seorang guru harus bisa membuat buku kerja guru. Buku kerja tersebut terdiri dari buku kerja 1 sampai dengan buku kerja 4. Untuk menjalankan perannya dengan baik, maka seorang kepala sekolah harus mengetahui kendala atau pemasalahan yang dihadapi guru terkait kinerja guru dalam pembuatan administrasi dan juga kegiatan pembelajaran dikelas.

\section{METODE}

Penelitian ini dilaksanakan di SMPN 7 Nangapanda yaitu sejak bulan Oktober sampai Desember 2019. Subjek dalam penelitian ini adalah seluruh guru-guru SMPN 7 Nangapanda yang berjumlah 10 orang guru. Penelitian ini merupakan Penelitian Tindakan Sekolah (PTS). Prosedur PTS meliputi perencanaan, pelaksanaan, pengamatan, dan refleksi. Penelitian ini direncanakan dalam dua siklus, dimana gambaran pelaksanaan siklus dapat dilihat pada gambar 1 


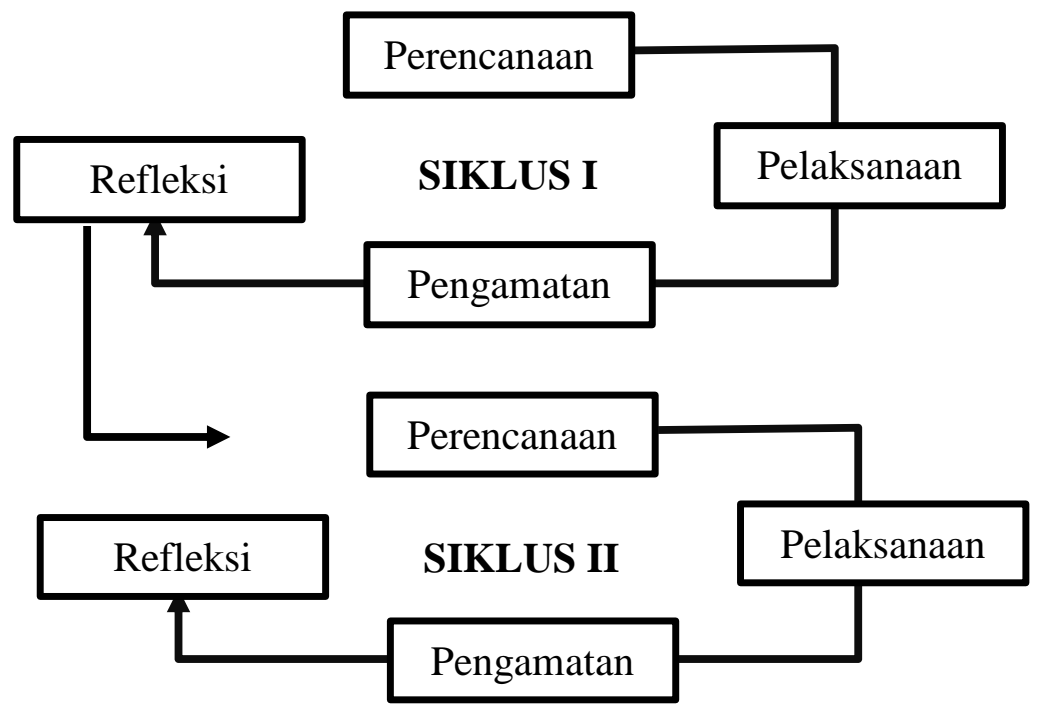

Gambar 1. Langkah-Langkah PTS (Direktorat Tendik, 2008, dalam Osnal, 2016)

Teknik pengumpulan data yang digunakan dalam penelitian ini terdiri dari; teknik observasi, wawancara, kuesioner, dan dokumentasi. Teknik analisis data yang digunakan adalah teknik analisis deskriptif kualitatif. Teknik analisis deskriptif adalah merupakan teknik analisis data dengan mendeskripsikan atau menggambarkan data-data yang sudah dikumpulkan tanpa bermaksud membuat generalisasi. Tahapan analisis ini yaitu; pengumpulan data, reduksi data atau penjaringan data, penyajian data, dan menarik kesimpulan.

Untuk menentukan keberhasilan tindakan dalan PTS ini perlu dibuat indikator-indikator keberhasilan PTS. Adapun indikator keberhasilan tindakan dalam PTS ini adalah sebagai berikut;

Tabel 1. Indikator Keberhasil PTS

\begin{tabular}{|c|l|l|}
\hline No & Indikator Keberhasilan & \multicolumn{1}{|c|}{ Target Keberhasilan } \\
\hline 1 & $\begin{array}{l}\text { Semakin meningkatnya } \\
\text { administrasi pembelajaran }\end{array}$ & $\begin{array}{l}\text { Ketuntasan Kelengkapan } \\
\text { administrasi mecapai 80\% } \\
\text { yang mendapat Nilai } \geq 75\end{array}$ \\
\hline 2 & Semakin berkualitas & $\begin{array}{l}\text { Katuntasan Pelaksanaan } \\
\text { pelaksanaan pembelajaran } \\
\end{array}$ \\
& $\begin{array}{l}\text { Pembelajaran mencapai } \\
80 \% \text { yang mendapat Nilai } \\
\geq 75\end{array}$ \\
\hline
\end{tabular}


Berikut adalah tabel hasil kinerja guru dalam bidang administrasi pembelajaran yang terjadi pada siklus I.

Tabel 2. Kinerja Guru Dalam Bidang Administrasi Pembelajaran

\begin{tabular}{|c|c|c|c|c|}
\hline \multirow{2}{*}{$\begin{array}{c}\text { Subjek } \\
\text { Peneltiian } \\
(N)\end{array}$} & \multicolumn{2}{|c|}{ Siklus I } & \multicolumn{2}{c|}{ Siklus II } \\
\cline { 2 - 5 } & Nilai & Kriteria & Nilai & Kriteria \\
\hline 01 & 78.26 & $\mathrm{~T}$ & 84.78 & $\mathrm{~T}$ \\
\hline 02 & 56.52 & $\mathrm{TT}$ & 80.43 & $\mathrm{~T}$ \\
\hline 03 & 54.34 & $\mathrm{TT}$ & 80.43 & $\mathrm{~T}$ \\
\hline 04 & 75.65 & $\mathrm{~T}$ & 84.78 & $\mathrm{~T}$ \\
\hline 05 & 82.60 & $\mathrm{~T}$ & 89.13 & $\mathrm{~T}$ \\
\hline 06 & 78.26 & $\mathrm{~T}$ & 84.78 & $\mathrm{~T}$ \\
\hline 07 & 73.91 & $\mathrm{TT}$ & 84.78 & $\mathrm{~T}$ \\
\hline 08 & 73.91 & $\mathrm{TT}$ & 84.78 & $\mathrm{~T}$ \\
\hline 09 & 73.91 & $\mathrm{TT}$ & 84.78 & $\mathrm{~T}$ \\
\hline 10 & 58.69 & $\mathrm{TT}$ & 80.43 & $\mathrm{~T}$ \\
\hline
\end{tabular}

Tabel di atas menunjukkan bahwa pada siklud I dari 10 orang guru sebagai subjek penelitian $(\mathrm{N})$, ketuntasan kinerja guru baru mencapai $40 \%$, atau 4 orang guru yang sudah mendapat nilai $\geq 75$. Hasil ini mengindikasikan bahwa target keberhasilan yaitu $80 \%$ belum tercapai, sehingga perlu dilanjutkan pada siklus 2. Hasil capaian yang diperoleh pada siklus II menunjukkan bahwa 100\% guru tuntas dalam kinerja bidang administrasi pembelajaran. Ada peningkatan yang signifikan dari ketuntasan kinerja guru yaitu dari 4 orang menjadi 10 orang guru atau presentasi peningkatan sebesar $60 \%$.

Berdasarkan tabel 2 di atas, untuk melihat kinerja guru berdasarkan 4 indikator maka dapat disederhanakan seperti pada tabel di bawah. Dari 4 indikator yang diukur, terlihat bahwa indikator pemetaan SKL-KI-KD mendapat mean 55 (kurang).

Tabel 3. Hasil Uji Statistik Deskriptif Kinerja Guru Dalam Bidang Administrasi Pembelajaran Berdasarkan Setiap Indikator

\begin{tabular}{|c|l|c|c|c|c|c|}
\hline No & \multicolumn{2}{|c|}{ Indikator } & N & \multicolumn{2}{c|}{ Siklus I } & \multicolumn{2}{c|}{ Siklus II } \\
\cline { 4 - 7 } & & & Mean & Kategori & Mean & Kategori \\
\hline 1 & $\begin{array}{l}\text { Pemetaan } \\
\text { SKL-KI-KD }\end{array}$ & 10 & 55 & Kurang & 77,50 & Baik \\
\hline 2 & Silabus & 10 & 73,75 & Baik & 87,50 & Sangat Baik \\
\hline 3 & RPP & 10 & 73,25 & Baik & 80,80 & Baik \\
\hline 4 & KKM & 10 & 76,60 & Baik & 100 & Sangat Baik \\
\hline
\end{tabular}

Dalam menilai kinerja guru bidang administrasi pembelajaran terdapat 4 indikator yang diukur seperti terlihat pada tabel 3. Hasil analisis pada siklus I menunjukkan bahwa kinerja guru pada indikator pemetaan SKL-KI-KD mendapat kategori kurang dengan nilai rata-rata (mean) yang diperoleh sebesar 55. Sedangkan tiga indikator lainnya masuk pada kategori baik. Pada siklus II 4 indikator kinerja guru mengalami peningkatan yang cukup 
signifikan. Hasil ini ditujukkan dari mean yang diperoleh yaitu di atas batas ketuntasan minimum sebesar $75 \%$.

Tabel 4. Kinerja Guru Dalam Bidang Pelaksanaan Pembelajaran

\begin{tabular}{|c|c|c|c|c|}
\hline \multirow{2}{*}{ Subjek } & \multicolumn{2}{|c|}{ Siklus I } & \multicolumn{2}{c|}{ Siklus II } \\
\cline { 2 - 5 } & Nilai & Kriteria & Nilai & Kriteria \\
\hline 01 & 95,12 & $\mathrm{~T}$ & 96,70 & $\mathrm{~T}$ \\
\hline 02 & 79,67 & $\mathrm{~T}$ & 88,60 & $\mathrm{~T}$ \\
\hline 03 & 74,79 & $\mathrm{TT}$ & 84,50 & $\mathrm{~T}$ \\
\hline 04 & 77,23 & $\mathrm{~T}$ & 87,80 & $\mathrm{~T}$ \\
\hline 05 & 79,67 & $\mathrm{~T}$ & 87,80 & $\mathrm{~T}$ \\
\hline 06 & 79,67 & $\mathrm{~T}$ & 89,40 & $\mathrm{~T}$ \\
\hline 07 & 83,73 & $\mathrm{~T}$ & 92,60 & $\mathrm{~T}$ \\
\hline 08 & 66,00 & $\mathrm{TT}$ & 84,50 & $\mathrm{~T}$ \\
\hline 09 & 77,23 & $\mathrm{~T}$ & 84,50 & $\mathrm{~T}$ \\
\hline 10 & 59,34 & $\mathrm{TT}$ & 84,50 & $\mathrm{~T}$ \\
\hline
\end{tabular}

Terdapat 3 indikator kinerja guru dalam bidang pelaksanaan pembelajaran, yaitu kegiatan pendahuluan, kegiatan inti, dan kegiatan penutup. Berdasarkan hasil analisis yang ditunjukkan pada tabel 4 , pada siklus I terdapat 3 orang guru tidak tuntas karena mendapat nilai masih dibawah standar yang ditetapkan yaitu 75 . Sedangkan pada siklus II seluruh subje atau sebanyak 10 orang guru telah tuntas dalam melaksanakan kinerja pelaksanaan pembelajaran. Besarnya presentasi peningkatan yaitu 30\%, dimana dari 7 orang yang telah tuntas pada siklus I meningkat menjadi 10 pada siklus II.

Dari hasil penelitian di atas menunjukkan bahwa pelaksanaan supervisi kepala sekolah secara individu ternyata mampu meningkatkan kinerja guru bidang administrasi pembelajaran dan bidang pelaksanaan pembelajaran di SMPN 7 Nangapanda. Hal ini memberikan gambaran bahwa ada pengaruh pelaksanaan supervisi kepala sekolah terhadap hasil kinerja guru. Hasil ini didukung oleh pendapat Hamailk (2006: 63), bahwa untuk meningkatkan kinerja guru faktor penting yang tidak dapat diabaikan adalah pelaksanaan supervisi kepala sekolah yang ideal dan sesuai dengan langkah kerja yang benar. Supervisi yang mengandung arti semua usaha yang dilakukan sepervaisor dalam bentuk pemberian bantuan, bimbingan, pergerakan motivasi, nasihat, dan pengarahan yang bertujuan untuk meningkatkan kemampuan guru dalam proses pembelajaran, yang pada akhirnya dapat meningkatkan hasil belajar siswa.

Hasil penelitian yang dilakukan Martina Yasinta Ngozo berkaitan dengan kinerja guru bidang administrasi menunjukkan bahwa ada peningkatan dalam pengembangan perangkat pembelajaran dan pelaksanaan pembelajaran dari sikulus I ke siklus II (Martina, 2019: 78). Hasil penelitian yang dilakukan Nurfatah (2018), juga memberikan hasil bahwa, agar para guru mampu melaksanakan tugas-tugas mulia yang menjadi tanggung jawabnya di sekolah, maka guru perlu senantiasa mendapat penyegaran dalam bentuk bantuan teknis sebagai upaya peningkatan kinerjanya, dimana bantuan tersebut dalam bentuk supervisi akademik yang dilakukan kepala sekolah dan pengawas. Selain itu penelitian yang dilakukan oleh Edi Rismawan (2015) memberikan hasil bahwa supervisi kepala sekolah berpengaruh terhadap kinerja mengajar guru.

Supervisi kepala sekolah yang merupakan fakator organisasional dapat mendorong tumbuhnya upaya dan motivasi guru dalam meningkatkan kinerja guru. Faktor pendorong dari dalam diri seorang guru tentunya sangat penting namun demikian, rangsangan dari luar pun menjadi sangat penting untuk terus meningkatkan kinerja guru. Peran kepala 
sekolah tentunya bisa sangat penting untuk meningkatkan kemampuan dan keterampilan para guru. oleh karena itu, supervisi kepala sekolah diharapkan bisa meningkatkan kemampuan guru dan kinerja guru untuk mencapai prestasi yang baik.

\section{PENUTUP}

Kesimpulan dari hasil penelitian ini adalah;

1. Ada peningkatan kinerja guru bidang administrasi pembelajaran yaitu ditunjukkan dari hasil yang diperoleh pada siklus I dimana dari 4 orang guru yang tuntas (40\%), dan pada siklus II meningkat menjadi 10 orang telah tuntas (100\%).

2. Ada peningkatan kinerja guru bidang pelaksanaan pembelajaran yaitu ditunjukkan dari hasil yang diperoleh pada siklus I dimana 7 orang guru yang tuntas (70\%), dan pada siklus II meningkat menjadi 10 orang telah tuntas (100\%).

\section{UCAPAN TERIMA KASIH}

Terima kasih bagi seluruh guru-guru di SMPN 7 Nangapanda yang sangat kooperatif dalam pelaksanaan penelitian ini, dan juga bagi Bapak/Ibu Dosen Program Studi Pendidikan Fisika yang telah memberikan pelatihan dan pendampingan, sehingga penelitian ini dapat berjalan dengan baik.

\section{DAFTAR PUSTAKA}

Edi Rismawan, (2015). Pengaruh Supervisi Kepala Sekolah dan Motivasi Berprestasi Guru Terhadap Kinerja Mengajar Guru. Jurnal Administrasi Pendidikan. Vol. XXII No. 1 April 2015.

Erni Agustina Suwartini. (2017). Supervisi Akademik Kepala Sekolah, Profesionalisme Guru, dan Mutu Pendidikan. Jurnal Administrasi Pendidikan. Vol. XXIV No. 2 Oktober 2017 62-70

Glikman, C.D., Gordon, S.P., \& Gordon, J.M.R. (2007). Supervision and Instructional Leadrship A Developmental Approach. Seventh Edition. New York: Perason Education, Inc.

Karsiyem, Muhammad Nur Wangid. (2015). Pelaksanaan Supervisi Akademik Dalam Meningkatkan Kinerja Guru Sekolah Dasar Gugus III Sentolo Kulon Progo. Jurnal Akuntabilitas Manajemen Pendidikan. Vol. 3(2) 201-212. Online:http//journal.uny.ac.id/index.php/jamp

Martina Yasinta Ngozo. (2019). PENERAPAN SUPERVISI AKADEMIK UNTUK MENINGKATKAN PEMAHAMAN GURU-GURU SDK WATUROKA MENGENAI PEMBELAJARAN KONTEKSTUAL. OPTIKA: Jurnal Pendidikan Fisika, 3(1), 78-84. Retrieved from http://ejournal.uniflor.ac.id/index.php/optika/article/view/118

Mulyasa, E. (2013). Uji Kompetensi dan Penilaian Kinerja Guru. Bandung: PT Remaja Rosdakarya.

Nurfatah \& Nur Rahmad. (2018). Pelaksanaan Supervisi Kepala Sekolah dan Pengawas Sekolah. Jurnal Manajemen,Kepemimpinan, dan Seupervisi Pendidikan. Vol. 3 (1) Januari 2018.

Osnal, (2016). Meningkatkan Kualitas Pembelajaran Guru Kelas 6 Melalui Supervisi Kelas Bersahabat di Gugus I Kecamatan Sumbermalang Kabupaten Situbondo Tahun Pelajaran 2015/2016. Jurnal Pancaran, Vol. 5, No. 1 (hal. 133-146) Pebruari 2016.

Sa’ud, U.S. (2011). Pengembangan Profesi Guru. Bandung: Alfabeta. 
Suhardan, D. (2010). Supervisi Profesional. Bandung: Alfabeta

Suharsaputra, U. (2010). Administrasi Pendidikan. Bandung: PT. Refika Aditama.

Supardi. (2013). Kinerja Guru. Jakarta: PT. Raja Grafindo Persada.

Undang-Undang Republik Indonesia Nomor 14 Tahun 2005 Pasal 8 Tentang Guru dan Dosen

Uno, H.B. dan Lamatenggo, N. (2012). Teori Kinerja dan Pengukurannya. Jakarta: Bumi Aksara.

Wayan, AS (2010). Akuntabilitas Kinerja Kepala Sekolah dan Penelitian Tindakan Sekolah Untuk Kepala Sekolah Dalam Rangka Peningkatan Mutu Pembelajaran Serta Bahan Belajar Mandiri Dimensi Kompetensi Kepala Sekolah. Jakarta: Az-Zahra Books 8.

Wiwin Kodariah, Endang Herawan, Cicih Sutrasih. (2016). Supervisi Akademik Kepala Sekolah, Motivasi Berprestasi Guru dan Kinerja Mengajar Guru. Jurnal Administrasi Pendidikan. Vol. XXIII No. 2 tahun 2016 123-133 